\title{
Differential incidence of the lemma on seed germination among different Paspalum dilatatum genotypes ${ }^{1}$
}

\author{
Nicolás Glison²*, Luis Viega², Pablo Speranza ${ }^{2}$
}

\begin{abstract}
Paspalum dilatatum Poir. is a promising perennial summer grass forage for temperate regions, but among other factors, slow stand establishment has hindered its adoption. One of the reasons may be seed dormancy. Intraspecific variability in seed dormancy has been reported in P. dilatatum, but the mechanisms underlying this variability remain unclear. In this paper, we focus on the role of seed external covering structures on germination, particularly the lemma. Seeds of apomictic and sexual biotypes of $P$. dilatatum were subjected to acid scarification and removal of the lemma to study their germination, imbibition rate and sensitivity to ABA. Seeds without lemma showed higher germination than other treatments in dormant genotypes. We found that the lemma delayed but did not prevent water uptake in any genotype. Comparing sexual biotypes, $P$. dilatatum subsp. flavescens showed higher lemma-imposed dormancy than P. dilatatum "Virasoro", and also higher seed dormancy at the caryopsis level. The thickness of the lemma was not different between these biotypes, so this trait did not explain differences in dormancy. Intraspecific variability of seed dormancy in this species may be attributable to the lemma incidence, however differences in the caryopsis component of seed dormancy should be considered.
\end{abstract}

Index terms: perennial warm-season forage grasses, seed dormancy, seed covering structures, acid scarification.

\section{Impacto diferencial da lema sobre a germinação de sementes entre diferentes genótipos de Paspalum dilatatum}

\begin{abstract}
RESUMO - Paspalum dilatatum Poir. é uma gramínea forrageira perene de regiões temperadas, mas sua utilização é limitada pelo seu estabelecimento lento, entre outros fatores. Uma razão pode ser a dormência das sementes. Tem sido relatada variabilidade intraespecífica da dormência em $P$. dilatatum, mas os mecanismos envolvidos nesta variabilidade não são claros. Neste trabalho estudamos o papel das coberturas externas sobre a germinação, particularmente da lema. Sementes de biótipos sexuais e apomíticos de $P$. dilatatum foram submetidos à escarificação ácida e remoção da lema para estudar a germinação, a taxa de embebição e a sensibilidade ao ABA. As sementes sem lema mostraram maior germinação que outros tratamentos em genótipos com dormência. Ainda, a lema retarda, mas não impede a entrada de água. Comparando genótipos sexuais, $P$. dilatatum subsp. flavescens apresentou uma maior dormência imposta pela lema que $P$. dilatatum "Virasoro", e também dormência mais elevada ao nível do cariopse. A espessura da lema não foi diferente entre estes genótipos, e portanto esta não explicou as diferenças na dormência. A variabilidade intraespecífica da dormência nesta gramínea panicóide pode ser atribuída às diferenças na incidência da lema. Contudo, diferenças na dormência ao nível da cariopse devem ser consideradas.
\end{abstract}

Termos de indexação: gramínea forrageira perene estival, dormência das sementes, coberturas externas das sementes, escarificação ácida.

\section{Introduction}

Paspalum dilatatum Poir. is a perennial warm-season grass that has been proposed as a warm-season forage crop in temperate regions, but like most wild perennial grasses, establishment is too slow for commercial adoption. Similar limitations have been reported in several other warm-season grasses, one of the causes contributing to slow establishment

${ }^{1}$ Submitted on 09/13/2016. Accepted for publication on 03/13/2017.

${ }^{2}$ Departamento de Biologia Vegetal, Facultad de Agronomía, Universidad de la República, 12900 - Montevideo, Uruguay.

*Corresponding author <nigli@fagro.edu.uy> 
may be seed dormancy (Adkins et al., 2002), for this reason, it is interesting to understand the mechanisms underlying seed dormancy in these species. Natural genetic variability has been reported for $P$. dilatatum in its native range (southeastern South America) (Speranza, 2009). The species comprises several apomictic clones and some sexual biotypes, including P. dilatatum subsp. flavescens Roseng, Arrill., Izag. (Flavescens) and P. dilatatum biotype 'Virasoro' (Virasoro). Genetic variability is reflected in several morpho-physiological differences (García et al., 2007; Couso et al., 2010), and differences in seed dormancy and in dry storage requirements to release primary dormancy, i.e. dry after-ripening (Tischler and Burson, 1999; Glison et al., 2015). Several methods and conditions have been reported to overcome dormancy such as light, nitrate, alternating temperatures and cold stratification (Schrauf et al., 1995); however, the responses of the different biotypes to these treatments are different (Glison et al., 2015).

Seed dormancy in warm-season grasses can be divided into two main components: coat and embryo dormancy (Adkins et al., 2002). The coat component could be due to the effect of external (floral) covering structures and/or caryopsis coats. Similar to most members of the subfamily Panicoideae, the seeds of $P$. dilatatum are complete spikelets with caryopsis strongly enclosed by rigid floret parts, the lemma and palea. The removal or mechanical damage of these external coats, or acid scarification treatments, may increase germination in several conditions, and the main mechanisms proposed are related to an interference of these structures to water uptake and gas exchange, or exert a mechanical restriction to embryo germination (Fulbright and Flenniken, 1988; West and Marousky, 1989; Usberti and Martins, 2007; Gallart et al., 2008). Although for Paspalum species the external covering structures seem to play a major role on seed dormancy, it is not clear whether the observed variability in seed dormancy may be due to differences at the level of the lemma and palea.

In several grass species, seed dormancy at the caryopsis level has been demonstrated, which is due to embryo dormancy and the interaction between seed coats and the embryo (Simpson, 2007; Rodríguez et al., 2015). Abscisic acid (ABA) is a phytohormone largely implicated in the imposition and maintenance of embryo dormancy (Finkelstein et al., 2008). When ABA is added to germination substrates, it inhibits seed germination by limiting embryo potential growth (FinchSavage and Leubner-Metzger, 2006). Both in domesticated and wild grass species, non-dormant genotypes or seeds with lowered seed dormancy - achieved by stratification or afterripening - exhibit a higher germination response to increasing exogenous ABA levels, i.e. less sensitivity to ABA (Romagosa et al., 2001; Gianinetti and Vernieri, 2007; Goggin et al., 2009; Mares and Mrva, 2014). Thus, ABA sensitivity could be assayed to compare levels of seed dormancy, specifically at the caryopsis or embryo level. There are few studies on germination responses to exogenous ABA of panicoid grasses and the results are similar to those found in other grass sub-families (Sarath et al., 2007; Duclos et al., 2014).

In order to set the basis for breeding towards reduced seed dormancy, it is necessary to provide a set of suitable traits to identify those genotypes with higher germination ability. Among possible traits, the evaluation of differential lemma incidence on germination seems to be important. In the present work, we studied the germination response and sensitivity to ABA of different $P$. dilatatum genotypes, emphasizing the sexual biotypes Flavescens and Virasoro, in recently harvested and after-ripened seeds subjected to the extraction of the lemma or acid scarification. In addition, we studied water uptake dynamics for each treatment and basic physical characteristics of the lemmas that could be associated with the germination response of each genotype.

\section{Materials and Methods}

\section{Plant material, seed harvest and dry storage conditions}

Seven genotypes of $P$. dilatatum, representing part of the natural genetic variability described by Speranza (2009), were evaluated for germination behaviour. These genotypes included four pentaploid apomictic clones of $P$. dilatatum subsp. dilatatum (A3, B1, C3 and D2), one inbred line from each of the sexual biotypes Flavescens and Virasoro, and one hexaploid apomictic clone (Chirú). Five individual plants of each genotype were grown in pots $(22 \mathrm{~cm}$ diameter, $19 \mathrm{~cm}$ deep) in a greenhouse without environmental control for three years (2009 to 2012) in Montevideo, Uruguay. Seeds were harvested weekly during January 2012 to compose one seed lot for each genotype. Each seed lot was cleaned with a seed blower and manually screened to separate empty spikelets or spikelets containing Claviceps sclerotia. The seeds were stored in paper envelopes within a closed chamber in the dark without temperature control (average $22.0 \pm 5.6^{\circ} \mathrm{C}$ ). Seeds from each lot were evaluated after one and five months of dry storage.

\section{Seed coat treatments}

Seeds of each genotype and storage time were subjected to the following coat treatments: i) seeds without modification (control), ii) seeds submerged in $18.4 \mathrm{M}$ $\mathrm{H}_{2} \mathrm{SO}_{4}$ for two minutes with stirring and then washed with running tap water (scarified), and iii) seeds from which the section of the lemma above the embryo was removed (without lemma, WOL). To achieve this, seeds were 
moistened for $2 \mathrm{~h}$ and the distal part of the seed covering structure was cut using tweezers and a razor blade under a stereoscopic magnifier without damaging other structures of the caryopsis; then, the lemma was carefully lifted and removed. After this procedure, exposed caryopses remained accompanied by the whole palea and few lateral sections of the lemma (Figure 1). When damage to the caryopsis coat was detected, the seed was discarded.

\section{Germination assays}

Seeds were sampled at each storage time (one and five months). At each sampling time, an experiment was set up in a randomized complete block design with three replications. The three seed coat treatments (control, scarified and WOL) and the seven genotypes (A3, B1, C3 and D2, Flavescens, Virasoro and Chirú) were arranged in a split-plots design, with treatments as major plots and genotypes as minor plots. Each experimental unit consisted of plastic Petri dishes with thirty seeds of a given genotype subjected to one treatment. For each storage time, the nine resulting trays were assayed simultaneously. Germination was carried out on moist filter paper, in $10 \mathrm{~cm}$ plastic Petri dishes. The filter paper was initially moistened with $0.2 \% \mathrm{KNO}_{3}$ solution and then moistened with distilled water when necessary. The Petri dishes were placed into an incubation chamber with fluorescent lighting $\left(15-20 \mu \mathrm{mol}\right.$ photons $\left.\mathrm{m}^{-2} \cdot \mathrm{s}^{-1}\right)$ at $32{ }^{\circ} \mathrm{C}$ for 14 days. At the end of each germination assay, final germination percentages were recorded and ungerminated seeds were tested for viability using the tetrazolium test. Viability percentages were calculated by adding the number of tetrazolium positive seeds to the number of germinated seeds. Germination and viability ratios were analysed using the GENMOD procedure (SAS 9.2, SAS Inst.), assuming a binomial distribution and combining all the data in a single model including both storage times. Mean comparisons were carried out with Tukey test at $0.05 \%$ when appropriate.

\section{ABA sensitivity assays}

ABA sensitivity assays were conducted for each storage time (one and five months) as randomized complete design experiments with three replications. Twenty control and WOL seeds from Flavescens and Virasoro were placed on an $1 \%$ agar $-0.2 \% \mathrm{KNO}_{3}$-water substratum with increasing concentrations of $\operatorname{ABA}(0,0.1,1.0$ and $10 \mu \mathrm{M})$ in $10 \mathrm{~cm}$ glass Petri dishes, following Goggin et al. (2009). The Petri dishes with the appropriate $\mathrm{ABA}$ concentration for each treatment were prepared and stored at $5{ }^{\circ} \mathrm{C}$ until used. Because germination conditions described above $\left(32{ }^{\circ} \mathrm{C}\right.$ constant) are limiting for the germination of freshly harvested seeds, stratification at $20^{\circ} \mathrm{C}$ was carried out to break dormancy in order to observe the effect of the addition of ABA (Glison et al., 2015). Petri dishes with seeds were placed at $20^{\circ} \mathrm{C}$ in the dark for the first seven days, and then transferred to $32{ }^{\circ} \mathrm{C}$ with light for 14 additional days. Germination counts were recorded after the first seven days $\left(G_{7}\right)$, and then daily for the subsequent 14 days to determine the final germination ratio $\left(G_{\text {tot }}\right)$. At the end of each germination assay, ungerminated seeds were tested for viability using the tetrazolium test. For analysis, data of both storage times were combined in a single model, considering storage time as major plots, ABA concentration and genotypes as sub-plots, and seed coat treatment as sub-sub-plots. Germination and viability ratios were analysed by using the GENMOD procedure as described above. Mean comparisons were carried out with the Tukey test at $0.05 \%$.

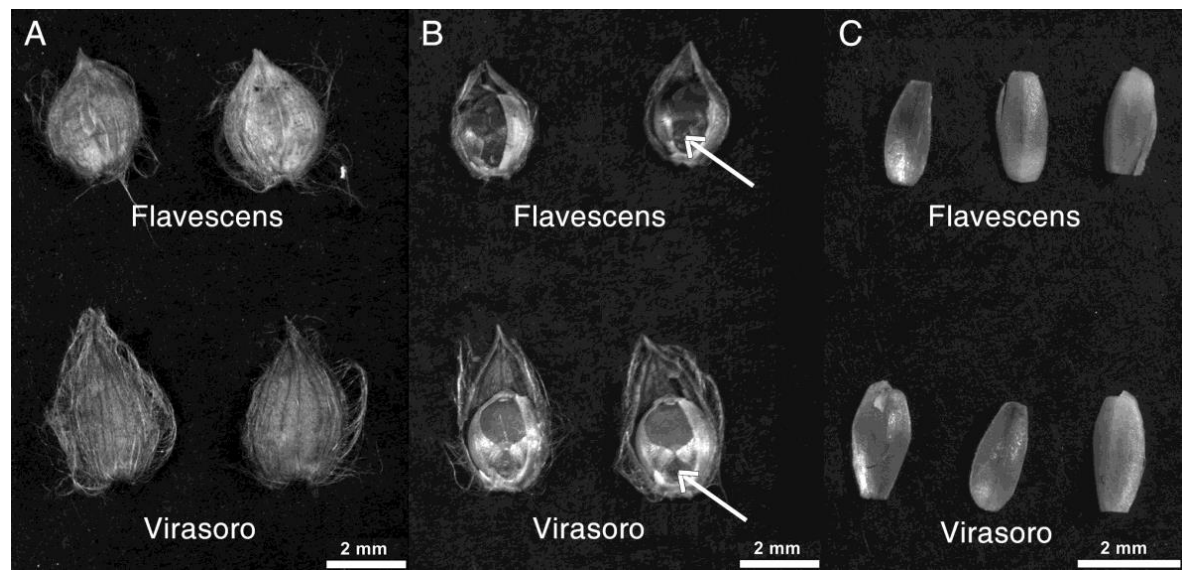

Figure 1. Images of Flavescens and Virasoro seeds. A: whole spikelets (control seeds). B: seeds without lemma (WOL seeds). The arrows indicate the position of the embryo. C: the extracted section of the lemma above the embryo. Bars $=2 \mathrm{~mm}$. 


\section{Imbibition assays}

Imbibition assays were conducted for both storage times (one and five months) as randomized complete block design experiments with three replications. The seeds of three genotypes: clone D2, Flavescens and Virasoro, were subjected to the three seed coat treatments described above, with some modifications: for the scarification treatment, seeds were air dried after scarification and before the imbibition assay, and for the seeds without lemma, the same procedure described above was performed, but on dry seeds. Thirty seeds were used for each treatment and genotype, and replicates were assembled on different days. The initial seed moisture content was similar among genotypes, with an average $9.3 \pm 0.9 \%$ and $13.8 \pm 1.4 \%$ (fresh weight basis) for one and five-month storage lots, respectively. Before each imbibition assay, bulk fresh seed weight $\left(\mathrm{FW}_{\mathrm{i}}\right)$ was recorded. Then, the thirty seeds were placed in Petri dishes between sheets of filter paper moistened with distilled water. Seeds were removed from moist filter paper, blotted dry superficially and weighted $\left(\mathrm{FW}_{\mathrm{t}}\right)$ after 10, 30, 60, 120, 240, 1440 and 2880 minutes $\left(6^{-1}\right.$, $2^{-1}, 1,2,4,24$ and 48 h, respectively). For each imbibition time, genotype and treatment, we calculated percent water uptake by seeds on initial fresh weight basis as: $\mathrm{WU}_{\mathrm{t}}=100$ $\left(\mathrm{FW}_{\mathrm{t}}-\mathrm{FW}_{\mathrm{i}}\right) / \mathrm{FW}_{\mathrm{i}}$, and the relative water uptake with water uptake at $48 \mathrm{~h}$ as maximum as: $\mathrm{RWU}_{\mathrm{t}}=100\left(\mathrm{WU}_{\mathrm{t}} / \mathrm{WU}_{\mathrm{t}=48 \mathrm{~h}}\right)$. The four variables $\left(\mathrm{FW}_{\mathrm{i}}, \mathrm{FW}_{\mathrm{t}=48 \mathrm{~h}}, \mathrm{WU}_{\mathrm{t}=48 \mathrm{~h}}\right.$ and $\left.\mathrm{RWU} \mathrm{t}_{\mathrm{t}}\right)$ were analysed with the MIXED procedure (SAS 9.2, SAS Inst.) in a single model including both storage times. Averages and standard deviations were estimated and mean comparisons were carried out with a Tukey test at $0.05 \%$. After $48 \mathrm{~h}$, seeds of each replicate were transferred to new Petri dishes with filter paper and $0.2 \% \mathrm{KNO}_{3}$ solution, and placed in $32{ }^{\circ} \mathrm{C}$ and light for 14 days. Estimation and analysis of final germination and viability ratios were performed as described above.

\section{Measures of the lemmas}

Extracted lemma sections (Figure 1C) from all experiments above were pooled, and eighteen lemmas were sampled for each genotype to measure length and width with a digital calliper. The thickness of each lemma was estimated under an optic microscope using a calibrated micrometer, as described by Jones and Nielson (1999). Six replicates of 20 lemmas were sampled for each genotype to determine their bulk weight. Averages and standard deviation were estimated for each measure by using the MIXED procedure (SAS 9.2, SAS Inst.), and mean comparisons were carried out with Tukey test at $0.05 \%$.

\section{Results and Discussion}

\section{Differential incidence of lemma on germination}

There were differences in seed germination among seed coat treatments and genotypes $(p<0.05)$. Seeds without lemma showed higher average germination ratio than scarified and control seeds for both storage times (Figure 2), and non-germinated seeds remained alive in a high proportion ( $88 \%$ in average). Chirú showed the highest germination percentages $(>80 \%)$ with no significant differences among seed coat treatments and storage times, similar to previous results (Glison et al., 2015), for this reason, this genotype was not considered in further analysis. In control seeds with one month of storage, the germination ratio was higher for Virasoro (27\%) than Flavescens and the pentaploid clones ( $2 \%$ on average). However, there were no differences in germination among these genotypes for WOL seeds. The
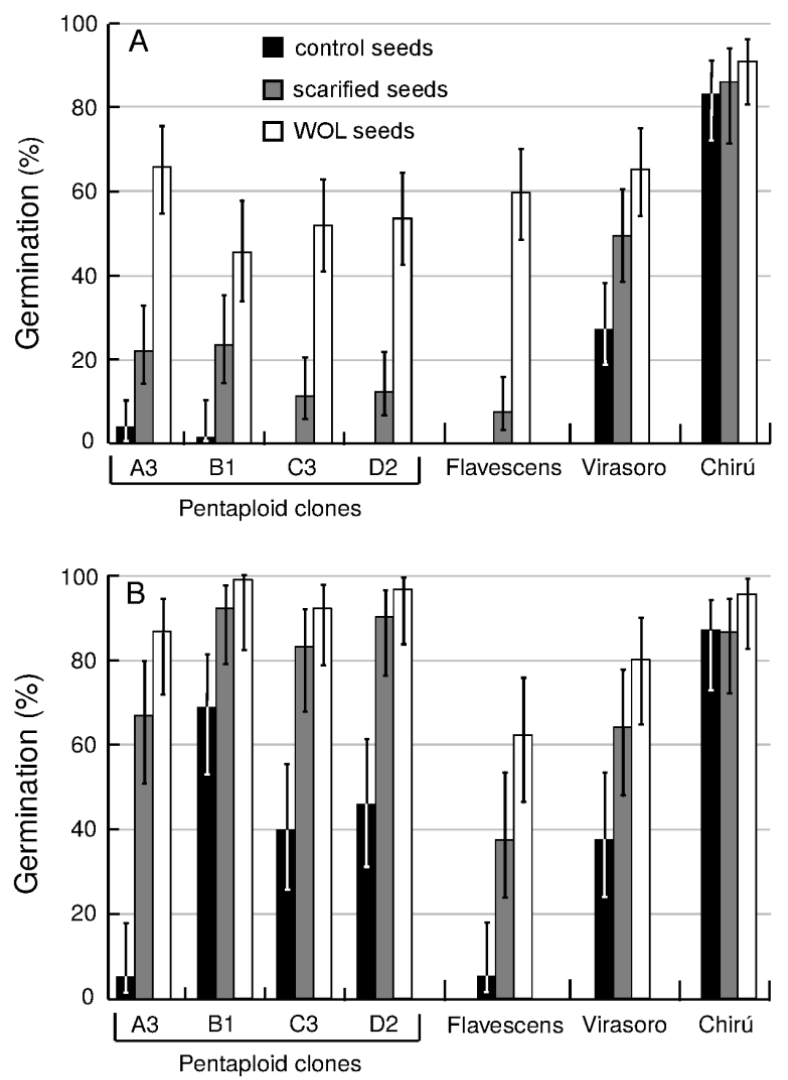

Figure 2. Average germination percentage after 14 days at $32{ }^{\circ} \mathrm{C}$ with light for seeds of different $P$. dilatatum genotypes and seed coat treatments. A: seeds with one month of dry storage. B: seeds with five months of dry storage. Vertical lines represent confidence limits at $95 \%$. 
average germination percentage for all of them was $57 \%$ (Figure 2A). In the ABA sensitivity assays, for seeds with one month of storage and the testing conditions assayed (7 d at $20{ }^{\circ} \mathrm{C}+14 \mathrm{~d}$ at $\left.32{ }^{\circ} \mathrm{C}\right), \mathrm{G}_{\text {tot }}$ without $\mathrm{ABA}$ was higher in WOL seeds of Flavescens compared to control seeds $(p<$ 0.05 ), but no differences between seed coat treatments were found for Virasoro (Figure 3A). These results suggest that the lemma imposes dormancy in seeds of $P$. dilatatum genotypes and its incidence is different among genotypes. The effect of the lemma on seed dormancy is greater in Flavescens than in Virasoro. The incidence of external covering structures on seed dormancy has been reported in several grasses (Simpson, 2007). In panicoid grasses, these structures are even more likely to affect germination, because the coleorhiza must emerge through a rigid lemma by opening a hinged flap named 'the germination lid' (Haar et al., 2014). Previous results in these species showed that extraction of the covering structures strongly promotes germination (Duclos et al., 2013), and the extraction of only the lemma had a similar or higher effect to the removal of both lemma and palea on germination in Digitaria sanguinalis (L.) Scop. (Gallart et al., 2008) and Paspalum notatum Flüggé (West and Marousky, 1989).

The thickness of the lemma is a genetically controlled trait related to dormancy in other grass species, such as Oryzopsis hymenoides [Roem. \& Schult.] Ricker ex Piper (Jones and Nielson, 1999) and Panicum miliaceum L. (Khan et al., 1997). We found no significant differences in length, width or thickness $(p>0.05)$ among the extracted sections of the lemma of Flavescens and Virasoro (Figure 1). Average values were 2.14 and $2.10 \mathrm{~mm}$ in length, 1.27 and $1.18 \mathrm{~mm}$ in width, and 304 and $286 \mu \mathrm{m}$ in thickness (CV thickness $=0.28$ ) for Virasoro and Flavescens, respectively. However, there was a significant effect of the genotype on the weight of the lemmas $(p<0.05)$. The 20 lemma sections of Flavescens were heavier than those of Virasoro (3.10 and $2.55 \mathrm{mg}$, respectively). These results suggest other possible structural differences which could in turn be associated with higher mechanical resistance to germination.

\section{The caryopsis component of dormancy}

The incidence of the lemma on seed dormancy was evident for most genotypes, but non-after-ripened WOL seeds never achieved germination percentages higher than $70 \%$ and no differences among genotypes were detected (Figure 2A). This behavior suggests a caryopsis component in all the $P$. dilatatum genotypes which showed seed dormancy. The ABA sensitivity assays was carried out to evaluate the deep of the caryopsis component for contrasting genotypes: Flavescens and Virasoro. A significant effect was only found after the addition of $10 \mu \mathrm{M}$ ABA (Figure 3). Lower concentrations of ABA $(0.1$ and $1.0 \mu \mathrm{M})$ showed no significant effect on any seed lot ( $\mathrm{p}>0.05$, data not shown). In other panicoid grasses, such as Panicum virgatum, $10 \mu \mathrm{M}$ was also the concentration of ABA which allowed the highest discrimination among genotypes (Duclos et al., 2014). In WOL seeds with one month of storage, $10 \mu \mathrm{M}$ ABA decreased the average $G_{\text {tot }}$ for both genotypes significantly in a similar magnitude, but differences between these genotypes in WOL seed germination after the first seven days of incubation at $20^{\circ} \mathrm{C}\left(\mathrm{G}_{7}\right)$ were found (Figure 3A). WOL seeds of Virasoro consistently showed a higher $\mathrm{G}_{7}$ ratio and a lower $A B A$ sensitivity (i.e. higher $G_{7}$ ratio with ABA) than Flavescens seeds (Figure 3A). These results suggest intraspecific differences in dormancy at the caryopsis level between Flavescens and Virasoro. Such dormancy
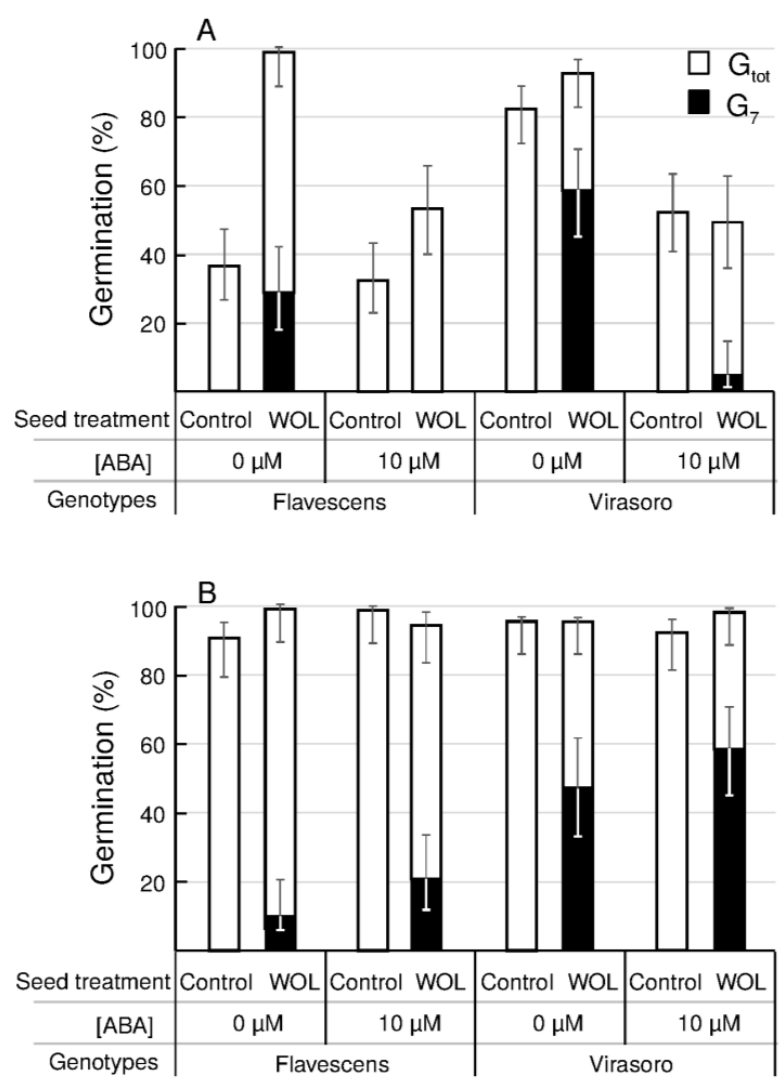

Figure 3. Average germination percentage in the first 7 days at $20^{\circ} \mathrm{C}\left(\mathrm{G}_{7}\right.$, black bars $)$ and final germination ratio obtained after an additional 14 days at $32{ }^{\circ} \mathrm{C}\left(\mathrm{G}_{\text {tot }}\right.$, white bars) for control and without lemma (WOL) seeds of the Flavescens and Virasoro biotypes, with and without the addition of $10 \mu \mathrm{M} \mathrm{ABA}$. A: seeds with one month of dry storage. B: seeds with five months of dry storage. Vertical lines represent confidence intervals at $95 \%$. 
component and the existence of intraspecific variability were reported in other panicoid grasses (Dekker et al., 1996; Gallart et al., 2008). In Panicum virgatum, it was suggested that dormancy at the caryopsis level is controlled by the caryopsis coat (pericarp/ testa complex) and even a slight disruption may cause an increase in germination, depending on the genotype (Duclos et al., 2013). More evidence is necessary to support the putative role of the caryopsis coat on seed dormancy in P. dilatatum.

\section{Germination was not associated to water uptake dynamics}

One major limiting factor for seed germination in some species is failure to achieve complete imbibition, and the external covering structures of some grasses have been reported to limit water uptake by the caryopsis (Simpson, 2007). To compare seed imbibition dynamics among genotypes and treatments, we used the relative water uptake $\left(\mathrm{RWU}_{\mathrm{t}}\right)$ because the percentage of water uptake $\left(\mathrm{WU}_{\mathrm{t}}\right)$ was different (Table 1), associated to the seed size of each genotype and the effect on seeds of each treatment. In our experiments, seeds seemed to reach full imbibition in all cases $\left(\mathrm{RWU}_{\mathrm{t}}=100 \%\right)$ before $24 \mathrm{~h}$ (Figure 4). However, the effect of seed coat treatment on water uptake dynamics was significant $(p<0.05)$. WOL seeds reached full imbibition in $120 \mathrm{~min}$ for all genotypes and storage times, earlier than both control and scarified seeds which showed no difference (Figure 4). When treatments were analysed separately, there were no differences in $\mathrm{RWU}_{\mathrm{t}}$ among genotypes or storage times $(p>0.05)$. These results suggest that seed covering structures delay water uptake but they are not an impermeable barrier for any of the genotypes evaluated. In other panicoid species, with similar results, it was concluded that seed dormancy expressed in each genotype is not due to a water uptake impediment by their covering structures (Huarte et al., 2007; Duclos et al., 2013). After the imbibition assays, seeds were tested for germination
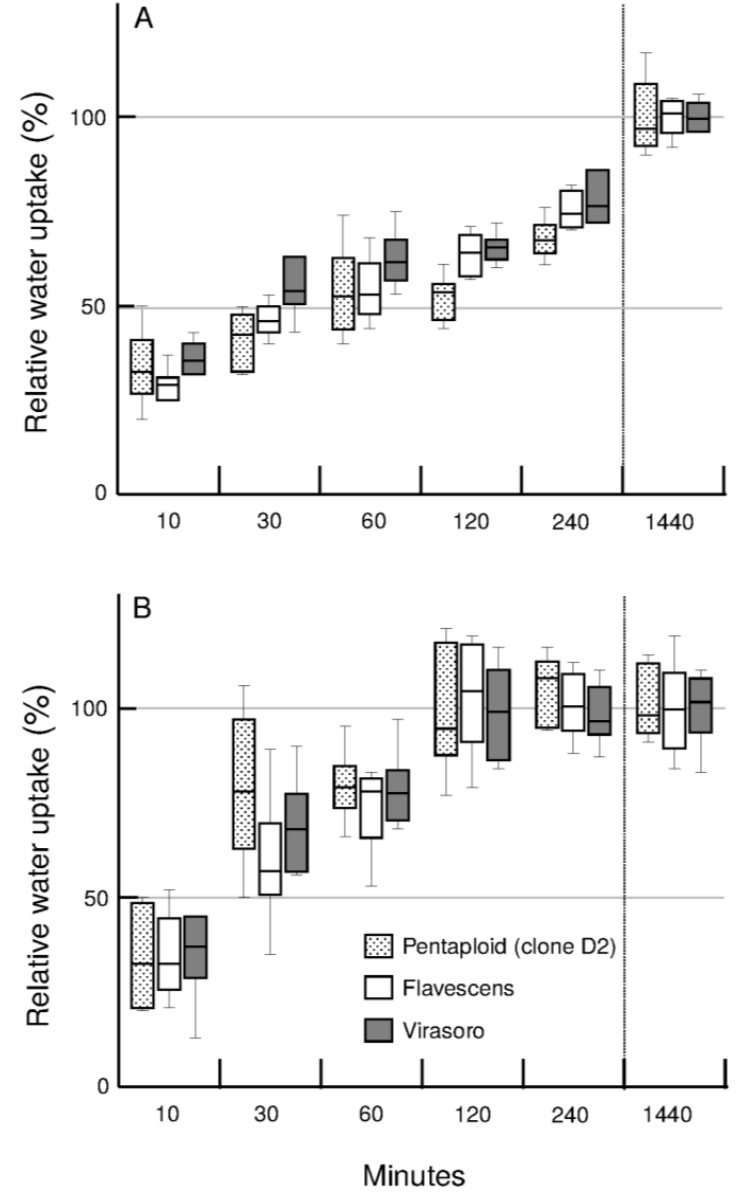

Figure 4. Box-plots of the percentage of relative water uptake for 30 seeds of a pentaploid clone (D2), Flavescens and Virasoro relative to water uptake after $48 \mathrm{~h}$ $\left(\mathrm{RWU}_{\mathrm{t}}\right)$. A: control seeds. Results from scarified seed were similar to control seeds (data not shown). B: without lemma seeds (WOL). Each box-plot included data from seeds with one and five months of storage for each genotype and seed coat treatment $(n=6)$.

Table 1. Weight of 30 fresh seeds before and after 48 hours of imbibition for each P. dilatatum genotype and seed coat treatment used in the imbibition assay. Values of each variable are mean \pm S.D. for both one and five month of storage $(n=6)$.

\begin{tabular}{|c|c|c|c|c|}
\hline \multirow{2}{*}{ Genotype } & \multirow{2}{*}{ Seed coat treatment } & \multicolumn{2}{|c|}{30 seeds weight $(\mathrm{mg})$} & \multirow{2}{*}{$\mathrm{WU}_{\mathrm{t}=48 \mathrm{~h}}(\%)$} \\
\hline & & $\mathrm{FW}_{\mathrm{i}}{ }^{1}$ & $\mathrm{FW}_{\mathrm{t}=48 \mathrm{~h}}$ & \\
\hline \multirow{3}{*}{ Pentaploid (clone D2) } & Control & $56.5 \pm 1.8 \mathrm{bc}$ & $74.7 \pm 2.7 \mathrm{bc}$ & $32.2 \pm 3.6 \mathrm{bc}$ \\
\hline & Scarified & $48.8 \pm 2.6 \mathrm{~cd}$ & $59.3 \pm 3.5 \mathrm{~cd}$ & $21.5 \pm 3.8 \mathrm{e}$ \\
\hline & $\mathrm{WOL}^{2}$ & $40.8 \pm 3.6 \mathrm{~d}$ & $51.1 \pm 3.8 \mathrm{~d}$ & $25.3 \pm 3.6 \mathrm{de}$ \\
\hline \multirow{3}{*}{ Flavescens } & Control & $69.8 \pm 7.3 \mathrm{a}$ & $97.7 \pm 12.9 \mathrm{a}$ & $39.8 \pm 4.3 \mathrm{a}$ \\
\hline & Scarified & $62.5 \pm 9.6 \mathrm{ab}$ & $77.7 \pm 10.9 \mathrm{~b}$ & $24.7 \pm 7.1 \mathrm{de}$ \\
\hline & WOL & $52.8 \pm 7.0 \mathrm{bc}$ & $65.8 \pm 8.4 \mathrm{bcd}$ & $24.7 \pm 3.2 \mathrm{de}$ \\
\hline \multirow{3}{*}{ Virasoro } & Control & $72.5 \pm 5.2 \mathrm{a}$ & $100.5 \pm 7.8 \mathrm{a}$ & $38.6 \pm 1.8 \mathrm{ab}$ \\
\hline & Scarified & $62.2 \pm 8.0 \mathrm{ab}$ & $78.6 \pm 11.1 \mathrm{~b}$ & $26.2 \pm 2.7 \mathrm{cde}$ \\
\hline & WOL & $54.8 \pm 4.5 \mathrm{bc}$ & $71.0 \pm 5.9 \mathrm{bc}$ & $29.5 \pm 3.2 \mathrm{~cd}$ \\
\hline
\end{tabular}

Same letter in a column means no significant difference (Tukey's test, $\alpha=0.05$ ).

${ }^{1} \mathrm{FW}_{\mathrm{i}}$ : initial fresh weight, $\mathrm{FW}_{\mathrm{t}=48 \mathrm{~h}}$ : fresh weight after $48 \mathrm{~h}$ of imbibition, $\mathrm{WU}_{\mathrm{t}=48 \mathrm{~h}}$ : percentage of water uptake after $48 \mathrm{~h}$ in seed fresh weight basis.

${ }^{2}$ WOL: Without lemma seeds. 
at $32{ }^{\circ} \mathrm{C}$. Despite the similarity in $\mathrm{RWU}_{\mathrm{t}}$ between control and scarified seeds, germination of scarified seeds was higher than control seeds (Table 2) and results were similar to those found in the initial germination experiment shown in Figure 2. However, WOL seeds reached full imbibition in 2 hours, but later, showed very low germination ratios because of a high proportion of dead seeds (Table 2). These results were very different from those obtained for WOL seeds in assays in which the lemma had been removed when imbibition had already started, which showed high germination and viability (Figure 2). For the imbibition assay, on the other hand, the lemmas were removed from the dry seeds before the onset of imbibition. Likely, the role of the lemma and palea on water uptake is to lower the rate of water uptake by the caryopsis to avoid embryo damage by imbibition. In Panicum miliaceum, genotypes with thinner lemmas take water faster and show more electric conductivity, an evidence of imbibition damage (Khan et al., 1997).

\section{Effect of dry storage}

Dry storage time, which causes after-ripening (a reduction in seed dormancy) in several panicoid grasses (Duclos et al., 2013; Glison et al., 2015), caused an increase in germination in almost all treatments for pentaploid clones (Figure 2), but no significant effect was observed on Virasoro and Flavescens ( $p>0.05$ ). However, after-ripening was evident for both sexual biotypes in the ABA sensitivity assays, since after 5 months of dry storage no effect of ABA on $G_{\text {tot }}$ or $G_{7}$ was observed on WOL or control seeds (Figure 3B). This effect of after-ripening recorded in both control and WOL seeds suggests that after-ripening affects both the caryopsis and the external covering structures. In previous works on other panicoid grasses such as Setaria faberii Herrm., it has been suggested that after-ripening affects seed dormancy at the caryopsis level (Dekker et al., 1996), rather than at the level of the lemma as suggested for P. notatum (West and Marousky, 1989). In most studied species, the effect of after-ripening on dormancy has been attributed to changes in gene expression related to $\mathrm{ABA}$ metabolism and $\mathrm{ABA}$ sensitivity, among other dormancy related genes (Iglesias-Fernández et al., 2011).

\section{Acid scarification and its effect on seed dormancy}

The effect of acid scarification is usually related to weakening the external covering structures and breaking physical dormancy in species other than grasses (Baskin et al., 2006). Scarification is frequently recommended in panicoid grasses, and it did promote germination in our assays. In our results, scarified seeds often showed higher germination than control seeds, but lower than WOL seeds (Figure 2), similar to results in other panicoid grasses (West and Marousky, 1989; Gallart et al., 2008). However, in other cases, scarification procedures resulted in higher germination ratios than the complete or partial removal of external covering structures (Fulbright and Flenniken, 1988). Also, treatments involving pricking both the lemma and caryopsis coat produced greater increases in germination than solely damaging or removing the external covering structures (Gallart et al., 2008; Duclos et al., 2013). Although there are evidences that acid scarification removes cuticular substances which fill the fissures of the germination lid (Marousky and West, 1988), the effect of acid scarification may not be only related to weakening the lemma and palea. It is also likely that acid also affects the caryopsis coat, promoting a break in dormancy at the caryopsis level.

\section{Conclusions}

The external covering structures do not prevent but delay water uptake by the caryopsis. This resistance is probably

Table 2. Germination and viability percentages after 14 days at $32{ }^{\circ} \mathrm{C}$ for each P. dilatatum genotype and seed coat treatment after $48 \mathrm{~h}$ of the imbibition assay. Results for each storage time are shown separately.

\begin{tabular}{|c|c|c|c|c|c|c|c|}
\hline \multirow{2}{*}{ Storage time } & \multirow{2}{*}{ Genotype } & \multicolumn{3}{|c|}{ Germination (\%) } & \multicolumn{3}{|c|}{ Viability (\%) } \\
\hline & & Control $^{1}$ & Scarified & WOL & Control & Scarified & WOL \\
\hline \multirow{3}{*}{ One month } & $\begin{array}{r}\text { Pentaploid } \\
\text { (clone D2) }\end{array}$ & $13 \mathrm{abA}$ & $38 \mathrm{abA}$ & $25 \mathrm{aA}$ & $90 \mathrm{aB}$ & $82 \mathrm{abB}$ & $26 \mathrm{aA}$ \\
\hline & Flavescens & $9 \mathrm{aA}$ & $15 \mathrm{aA}$ & $10 \mathrm{aA}$ & $93 \mathrm{aB}$ & $96 \mathrm{abB}$ & $10 \mathrm{aA}$ \\
\hline & Virasoro & $30 \mathrm{bcB}$ & $61 \mathrm{bB}$ & $2 \mathrm{aA}$ & $87 \mathrm{aB}$ & $83 \mathrm{abB}$ & $6 \mathrm{aA}$ \\
\hline \multirow{3}{*}{ Five months } & $\begin{array}{r}\text { Pentaploid } \\
\text { (clone D2) }\end{array}$ & $50 \mathrm{cAB}$ & $97 \mathrm{cB}$ & $15 \mathrm{aA}$ & $74 \mathrm{aB}$ & $99 \mathrm{aB}$ & $15 \mathrm{aA}$ \\
\hline & Flavescens & $17 \mathrm{abA}$ & $67 \mathrm{bB}$ & $12 \mathrm{aA}$ & $82 \mathrm{aB}$ & $91 \mathrm{abB}$ & $14 \mathrm{aA}$ \\
\hline & Virasoro & $45 \mathrm{cB}$ & $57 \mathrm{bB}$ & $6 \mathrm{aA}$ & $85 \mathrm{aB}$ & $76 \mathrm{bB}$ & $8 \mathrm{aA}$ \\
\hline
\end{tabular}

Same lower case letters in a column, or same capital letters in a row, means no significant difference (Tukey's test, $\alpha=0.05$ ).

${ }^{1}$ Seed coat treatments. WOL: without lemma seeds. 
more important to avoid imbibition damage than in the regulation of seed dormancy.

Although we observed differences in the incidence of the lemma on seed dormancy among genotypes, we did not find differences in its thickness which has frequently been related to seed dormancy.

The lemma-imposed component is relevant in the genotypes of $P$. dilatatum showing seed dormancy that we analysed here; however, there is a significant caryopsis component of seed dormancy which also may explain genetic variability in seed dormancy in these species.

\section{Acknowledgments}

We thank Prof. Diego Suárez, Bach. Isabel Aimé and Bach. Pablo Posada for their collaboration with seed assays, and Dr. Rafael Vidal for his review of the writing in portuguese. This work was funded by the Instituto Nacional de Investigación Agropecuaria, Uruguay (project FPTA 177) and the first author received a scholarship from the Agencia Nacional de Investigación e Innovación (BE_POS_2010_2497), Uruguay.

\section{References}

ADKINS, S.W.; BELLAIRS, S.M.; LOCH, D.S. Seed dormancy mechanisms in warm season grass species. Euphytica, v.126, n.1, p.1320, 2002. http://www.springerlink.com/index/k4w7t38464117670.pdf

BASKIN, C.C.; THOMPSON, K.; BASKIN, J.M. Mistakes in germination ecology and how to avoid them. Seed Science Research, v.16, n.3, p.165-168, 2006. http://journals.cambridge.org/article_ S0960258506000183

COUSO, L.L.; GATTI, M.L.; CORNAGLIA, P.S.; SCHRAUF, G.E.; FERNÁNDEZ, R.J. Are more productive varieties of Paspalum dilatatum less tolerant to drought? Grass and Forage Science, v.65, n.3, p.269-303, 2010. http://onlinelibrary.wiley.com/doi/10.1111/ j.1365-2494.2010.00748.x/full

DEKKER, J.; DEKKER, B.; HILHORST, H.; KARSSEN, C. Weedy adaptation in Setaria spp. IV. Changes in the germinative capacity of $S$. faberii (Poaceae) embryos with development from anthesis to after abscission. American Journal of Botany, v.83, n.8, p.979-991, 1996. http://www.jstor.org/stable/2445986

DUCLOS, D.V.; ALTOBELLO, C.O.; TAYLOR, A.G. Investigating seed dormancy in switchgrass (Panicum virgatum L.): Elucidating the effect of temperature regimes and plant hormones on embryo dormancy. Industrial Crops and Products, v.58, p.148-159, 2014. http://dx.doi.org/10.1016/j.indcrop.2014.04.011

DUCLOS, D.V.; RAY, D.T.; JOHNSON, D.J.; TAYLOR, A.G. Investigating seed dormancy in switchgrass (Panicum virgatum L.): understanding the physiology and mechanisms of coat-imposed seed dormancy. Industrial Crops and Products, v.45, p.377-387, 2013. http://linkinghub.elsevier.com/retrieve/pii/S0926669013000228
FINCH-SAVAGE, W.E.; LEUBNER-METZGER, G. Seed dormancy and the control of germination. New Phytologist, v.171, n.3, p.501523, 2006. http://doi.wiley.com/10.1111/j.1469-8137.2006.01787.x

FINKELSTEIN, R.; REEVES, W.; ARIIZUMI, T.; STABER, C. Molecular aspects of seed dormancy. Annual Review of Plant Biology, v.59, n.1, p.387-415, 2008. http://www.annualreviews.org/ doi/full/10.1146/annurev.arplant.59.032607.092740

FULBRIGHT, T.; FLENNIKEN, K. Causes of dormancy in Paspalum plicatulum (Poaceae) seeds. The Southwestern Naturalist, v.33, n.1, p.35-39, 1988. http://www.jstor.org/stable/10.2307/3672086

GALLART, M.; VERDÚ, A.M.C.; MAS, M.T. Dormancy breaking in Digitaria sanguinalis seeds: the role of the caryopsis covering structures. Seed Science and Technology, v.36, n.2, p.259-270, 2008. http://www.ingentaconnect.com/content/ista/ sst/2008/00000036/00000002/art00001

GARCÍA, M.V.; BALATTI, P.A.; ARTURI, M.J. Genetic variability in natural populations of Paspalum dilatatum Poir. analyzed by means of morphological traits and molecular markers. Genetic Resources and Crop Evolution, v.54, n.5, p.935-946, 2007. http:// www.springerlink.com/index/10.1007/s10722-006-9147-8

GIANINETTI, A.; VERNIERI, P. On the role of abscisic acid in seed dormancy of red rice. Journal of Experimental Botany, v.58, n.12, p.3449-3462, 2007. http://jxb.oxfordjournals.org/lookup/ doi/10.1093/jxb/erm198

GLISON, N.; VIEGA, L.; CORNAGLIA, P.; GUTIÉRREZ, L.; SPERANZA, P. Variability in germination behaviour of Paspalum dilatatum Poir. seeds is genotype dependent. Grass and Forage Science, v.70, n.1, p.144-153, 2015. http://doi.wiley.com/10.1111/ gfs. 12119

GOGGIN, D.E.; STEADMAN, K.J.; EMERY, R.J.N.; FARROW, S.C.; BENECH-ARNOLD, R.L.; POWLES, S.B. ABA inhibits germination but not dormancy release in mature imbibed seeds of Lolium rigidum Gaud. Journal of Experimental Botany, v.60, n.12, p.3387-3396, 2009. http://jxb.oxfordjournals.org/lookup/ doi/10.1093/jxb/erp175

HAAR, M.; VAN AELST, A.; DEKKER, J. Weedy adaptation in Setaria spp.: VIII. Structure of Setaria faberii seed, caryopsis and embryo germination. Quantitative Methods, v.1403, p.1-16, 2014. http://arxiv.org/abs/1403.7096

HUARTE, R.; STALTARI, S.; CHORZEMPA, S.E.; GARCÍA, M.D. Tripsacum dactyloides (L.) L. caryopses water uptake dynamics and germination responses to giberellic acid, fluctuating temperatures and pericarp scarification. Seed Science and Technology, v.35, n.2, p.255-265, 2007. http://www.ingentaconnect.com/content/ista/ sst/2007/00000035/00000002/art00001

IGLESIAS-FERNÁNDEZ, R.; RODRÍGUEZ, C.; MATILLA, A.J. Progress in research on dry after ripening. Seed Science Research, v.21, n.2, p.69-80, 2011. http://journals.cambridge.org/abstract S096025851000036X

JONES, T.; NIELSON, D. Intrapopulation genetic variation for seed dormancy in Indian ricegrass. Journal of Range Management, v.52, n.6, p.646-650, 1999. http://www.jstor.org/stable/10.2307/4003636 
KHAN, M.; CAVERS, P.B.; KANE, M.; THOMPSON, K. Role of the pigmented seed coat of proso millet (Panicum miliaceum L.) in imbibition, germination and seed persistence. Seed Science Research, v.7, n.1, p.21-25, 1997. http://journals.cambridge.org/production/ action/cjoGetFulltext?fulltextid=2206688

MARES, D.J.; MRVA, K. Wheat grain preharvest sprouting and late maturity alpha-amylase. Planta, v.240, n.6, p.1167-1178, 2014. http://www.ncbi.nlm.nih.gov/pubmed/25257145

MAROUSKY, F.; WEST, S. Germination of bahiagrass in response to temperature and scarification. Journal of American Society Horticultural Science, v.113, n.6, p.845-849, 1988. http://agris. fao.org/agris-search/search/display.do?f=1989/US/US89430. xml;US8901845

RODRÍGUEZ, M.V.; BARRERO, J.M.; CORBINEAU, F.; GUBLER, F.; BENECH-ARNOLD, R.L. Dormancy in cereals (not too much, not so little): about the mechanisms behind this trait. Seed Science Research, v.25, n.2, p.99-119, 2015. http://www.journals. cambridge.org/abstract_S0960258515000021

ROMAGOSA, I.; PRADA, D.; MORALEJO, M.A.; SOPENA, A.; MUÑOZ, P.; CASAS, A.M.; SWANSTON, J.S.; MOLINA-CANO, J.L. Dormancy, ABA content and sensitivity of a barley mutant to $\mathrm{ABA}$ application during seed development and after ripening. Journal of Experimental Botany, v.52, n.360, p.1499-1506, 2001. http://www.ncbi.nlm.nih.gov/pubmed/11457910

SARATH, G.; HOU, G.; BAIRD, L.M.; MITCHELL, R.B. Reactive oxygen species, ABA and nitric oxide interactions on the germination of warm-season C4-grasses. Planta, v.226, n.3, p.697-708, 2007. http:/www.springerlink.com/index/10.1007/s00425-007-0517-z
SCHRAUF, G.E.; CORNAGLIA, P.S.; DEREGIBUS, V.A.; RÍSSOLA, M.G. Improvement in germination behaviour of Paspalum dilatatum Poir seeds under different pre-conditioning treatments. New Zealand Journal of Agricultural Research, v.38, n.4, p.501-509, 1995. http://www.tandfonline.com/doi/abs/10.1080 $/ 00288233.1995 .9513152$

SIMPSON, G. Seed dormancy in grasses. Cambridge, UK.: Cambridge University Press, 2007. 308p.

SPERANZA, P. Evolutionary patterns in the Dilatata group (Paspalum, Poaceae). Plant Systematics and Evolution, v.282, n.1, p.43-56, 2009. http://www.springerlink.com/index/J08284XG44170673.pdf

TISCHLER, C.; BURSON, B.L. Seed dormancy and germination of dallisgrass, Paspalum dilatatum, stored under differing conditions. Seed Science and Technology, v.27, n.1, p.263-271, 1999. http://cat. inist.fr/?aModele $=$ afficheN\&cpsidt $=1897478$

USBERTI, R.; MARTINS, L. Sulphuric acid scarification effects on Brachiaria brizantha, B. humidicola and Panicum maximum seed dormancy release. Revista Brasileira de Sementes, v.29, n.2, p.143-147, 2007. http://www.scielo.br/scielo.php?pid=S0101$31222007000200020 \&$ script $=$ sci_arttext\&tlng $=$ pt

WEST, S.; MAROUSKY, F. Mechanism of dormancy in pensacola bahiagrass. Crop Science, v.29, n.3, p.787-791, 1989. https://www. crops.org/publications/cs/abstracts/29/3/CS0290030787 